\title{
REGIONALISMO SUL-AMERICANO NOS ANOS 2020: 0 QUE ESPERAR EM MEIO ÀS INSTABILIDADES POLÍTICAS?
}

\author{
Cairo Gabriel Borges Junqueira ${ }^{1}$ \\ Bárbara Carvalho Neves ${ }^{2}$ \\ Lucas Eduardo Silveira de Souza ${ }^{3}$
}

\begin{abstract}
Considerando a conjuntura vigente, o objetivo deste artigo é analisar o regionalismo sul-americano em face do enfraquecimento de sua vertente pós-hegemônica, das instabilidades políticas de seus países e do papel do Brasil nesse processo. Além de questionar como o atual regionalismo pode ser caracterizado, indagamos o que esperar na década de 2020 que se inicia. Por meio de análise bibliográfica, documental e de notícias, argumentamos que a criação de novos organismos regionais como o Fórum para 0 Progresso e Desenvolvimento da América do Sul (Prosul), a confluência de instabilidades políticas e sociais nos países da região e a mudança de orientação política do Brasil são características fundamentais que denotam certo grau de maior instabilidade no regionalismo sul-americano para os próximos anos.
\end{abstract}

Palavras-chave: regionalismo; América do Sul; política externa brasileira; Prosul.

\section{SOUTH AMERICAN REGIONALISM IN 2020: WHAT TO EXPECT AMIDST THE POLITICAL INSTABILITIES?}

Considering the current juncture this article's objective is to analyze South American regionalism facing the weakening of its post-hegemonic aspect, the political instabilities of its countries and the role of Brazil in this process. In addition to questioning how the current regionalism can be characterized, we ask what to expect from regionalism in the beginning decade of 2020. Through bibliographic, documentary and news analysis, we argue that the creation of new regional bodies such the Forum for the Progress of South America (PROSUR), the confluence of political and social instabilities in the countries of the region, and the changes in the Brazilian political orientation are fundamental characteristics that denote a certain degree of greater instability in South American regionalism for the upcoming years.

Keywords: regionalism; South America; Brazilian foreign policy; Prosur.

\footnotetext{
1. Professor do Departamento de Relações Internacionais da Universidade Federal de Sergipe (DRI/UFS) e doutor em relações internacionais pelo Programa de Pós-Graduação San Tiago Dantas (Unesp, Unicamp, PUC-SP). Atualmente é membro da Rede de Pesquisa em Política Externa e Regionalismo (Repri), do Observatório de Regionalismo (ODR) e do Núcleo de Estudos de Políticas Públicas (NEPPs). E-mail: <cairojunqueira@gmail.com>. Orcid: <https://orcid.org/0000-0002-3753-9769>.

2. Professora substituta do Departamento de Relações Internacionais da Faculdade de Ciências Humanas e Sociais - campus de Franca (DRI/Unesp); doutoranda e mestre pelo Programa de Pós-Graduação em Relações Internacionais - San Tiago Dantas (Unesp, Unicamp, PUC-SP) e membro da Repri, do ODR e do Laboratório de Novas Tecnologias de Pesquisa em Relações Internacionais (Lantri). E-mail: <barbara.neves@unesp.br>. Orcid: <https://orcid.org/0000-0001-8233-7309>. 3. Professor substituto da Faculdade de Direito e Relações Internacionais da Universidade Federal da Grande Dourados (Fadir/UFGD); mestre em relações internacionais (Instituto de Relações Internacionais da Universidade de Brasília - Irel/UnB); e membro do ODR, vinculado à Repri. E-mail: <ledusouza@gmail.com>. Orcid: <https://orcid.org/0000-0002-4242-1837>.
} 


\title{
REGIONALISMO SUDAMERICANO EN LOS AÑOS 2020: ¿QUÉ ESPERAR EN MEDIO DE LAS INESTABILIDADES POLÍTICAS?
}

\begin{abstract}
Tomando en consideración la coyuntura actual, el objetivo de este artículo es analizar el regionalismo sudamericano frente al debilitamiento de su aspecto post-hegemónico, de las inestabilidades políticas de sus países y del rol de Brasil en este proceso. Además de cuestionar cómo se puede caracterizar el regionalismo actual, preguntamos qué se puede esperar de él en la primer década de 2020 que comienza. A través del análisis bibliográfico, documental y de noticias, afirmamos que la creación de nuevos organismos regionales como Foro para el Progreso y Desarrollo de América del Sur (Prosur), así como la confluencia de inestabilidades políticas y sociales en los países de la región, y, además del cambio en la orientación política de Brasil, son características fundamentales que denotan un grado de mayor de inestabilidad en el regionalismo sudamericano para los próximos años.
\end{abstract}

Palabras clave: regionalismo; Sudamérica; política exterior brasileña; Prosur.

JEL: F5.

DOl: http://dx.doi.org/10.38116/rtm23art4

Data de envio do artigo: 27/4/2020; Data de aceite: 11/8/2020.

\section{INTRODUÇÃO}

Assim como os anos 2000 marcaram o aprofundamento das relaçóes de cooperação e integração na América do Sul com a criação de novas instituições regionais e a incorporaçáo de novos temas na agenda regional como a democracia, a igualdade social e a supressão de assimetrias no continente (Riggirozzi e Tussie, 2012), o fim da década de 2010 parece refletir cada vez mais um cenário de fragmentaçăo do espaço regional.

As mudanças políticas e econômicas que vêm ocorrendo no continente desde 2013 deram início à fragilização da coesão regional até então existente, representando um cenário futuro incerto para a integração regional (Neves e Honório, 2019; Sanahuja, 2019). A conjuntura crítica que se desenvolveu em algumas das principais economias sul-americanas, entre elas Brasil e Venezuela, representou não somente uma crise política e econômica interna a cada país, como também demarcou o crescente descrédito e desestímulo dos espaços regionais conformados, refletindo-se na interrupção dos encontros anuais de presidentes sul-americanos desde 2014.

Ainda assim, destaca-se que o aprofundamento das problemáticas nacionais a partir de 2010 acabou por resultar no desmantelamento das tratativas regionais, cujo ápice se deu com o desmantelamento da União de Naçôes Sul-Americanas (Unasul) após a saída de mais de metade de seus membros em abril de 2019 (Nolte, 2019), ao mesmo tempo que se conformava um novo mecanismo para "substituir" o bloco a partir de novas diretrizes, de menor institucionalização e maior foco comercial, o Fórum para o Progresso e Desenvolvimento da América do Sul (Prosul) (Palestini, 2019). 
Apesar do esvaziamento da Unasul, da criação de novos mecanismos como o Prosul, e até mesmo da retomada de ênfase dos espaços continentais como a Organização dos Estados Americanos (OEA), é notável que o regionalismo não está desaparecendo, mas, sim, adaptando-se e estruturando-se às novas demandas dos governos e das necessidades sul-americanas (Neves e Honório, 2019).

Diante dessas mudanças, como caracterizar o atual panorama do regionalismo sul-americano e o que esperar em meio às instabilidades políticas internas e externas dos países da região, com ênfase para o Brasil? Em busca de respostas, este trabalho objetiva analisar a atual conjuntura do regionalismo sul-americano, a partir do enfraquecimento de sua vertente pós-hegemônica, considerando as mudanças políticas domésticas e externas de seus países, com destaque para o caso brasileiro. Argumenta-se haver um conjunto de elementos de enfraquecimento do regionalismo pós-hegemônico, motivado, sobretudo, por uma guinada à direita da América do Sul, uma conjuntura de polarização e radicalização interna aos países e um vácuo de liderança regional a partir dos recuos da política externa brasileira.

A dinâmica regional estabelecida reflete sua vulnerabilidade frente à reconfiguração do cenário atual sul-americano, uma vez que as mudanças de ordem doméstica geram transformaçôes nas política exteriores dos países, as quais, por conseguinte, ditam o ritmo atual do regionalismo sul-americano. Novas eleiçóes regionais resultaram em modificaçóes nos direcionamentos políticos e econômicos, trazendo ao debate integracionista perspectivas antigas que apontam a intenção de retorno a um posicionamento mais liberal no continente (Palestini, 2019). Também abrem portas para a atuação de outros países na regiāo, trazendo outros interesses e possíveis desdobramentos desfavoráveis ao aprofundamento do projeto integracionista sul-americano defendido no marco da criação da Unasul (Nolte, 2019).

Para tanto, a partir da análise qualitativa de bibliografia, documentos e notícias, o estudo está estruturado em três partes, além desta introdução e das consideraçóes finais. Em um primeiro momento, este texto busca discutir o processo de enfraquecimento do regionalismo pós-hegemônico e as potenciais consequências dessa transição ante o novo contexto e demandas regionais. Em um período marcado pelo desmantelamento de instituições consolidadas, a criação de novos mecanismos a partir de novas lideranças, e a inserção de atores importantes na reconstrução do espaço regional, é necessário discutir o papel das instituiçôes regionais sob uma perspectiva de longo prazo.

Sendo assim, a segunda parte visa trazer luz aos levantes sociais que ocorreram em diferentes países da região, como Venezuela, Brasil, Bolívia, Chile e Equador, levando em consideração a relação de conflito entre o Estado, os setores produtivos e a sociedade, e o reflexo desses problemas nacionais no âmbito do regionalismo. 
Por fim, levando em conta a importância do Brasil na construção do espaço regional sul-americano das últimas décadas, a terceira parte do estudo analisa a política externa brasileira, considerando as atuais diretrizes do país e seu posicionamento perante seu entorno regional.

\section{ENFRAQUECIMENTO DO REGIONALISMO PÓS-HEGEMÔNICO}

Como modo de caracterizar as diferentes fases de integração e a formaçáo de organizaçóes regionais na América Latina, utiliza-se na literatura especializada da área a ideia de "ondas de regionalismo". ${ }^{4}$ Por "ondas" entendem-se os períodos e processos nos quais os blocos regionais foram guiados por interesses específicos inerentes a cada época. Já o regionalismo pode ser compreendido de maneira dupla, ora como processo político que estimula a integração regional, ora como uma área de pesquisa com o objetivo de entender diferentes processos de criação de instituiçóes regionais com participaçáo de distintos atores (Junqueira e Milani, 2019, p. 72).

Tal movimento iniciou-se na década de 1960, período em que a Comissão Econômica para a América Latina e o Caribe (Cepal), criada em 1948, estava preocupada em observar os movimentos estruturais em torno da industrializaçáo da regiáo e verificar como variáveis externas estavam condicionando patamares de subdesenvolvimento nos países (Bielschowsky, 1998). O grande debate do período, para se pensar o papel da América Latina em meio à Guerra Fria, estava centrado em questionar até que ponto determinados países, incluindo e destacando-se o próprio Brasil, ficavam à mercê dos interesses das grandes potências. Por exemplo, investigaçóes envolvendo diferentes níveis ora de autonomia, ora de dependência, foram fortemente estimuladas, sobretudo nas décadas de 1970 e 1980 (Jaguaribe, 2008).

Em meio à criação da Associaçáo Latino-Americana de Livre Comércio (ALALC), do Mercado Comum Centro-Americano (MCCA), ambos em 1960, e do Pacto Andino em 1969, formou-se a primeira onda denominada de "regionalismo fechado", perdurando até os anos 1980, no qual ocorreu a criação da Associação Latino-Americana de Integração (Aladi). Nessa etapa, a grande problemática era debater maiores níveis de desenvolvimento interno dos países em meio às suas inclusóes na cadeia global de comércio.

Posteriormente, nos anos 1990, tomou forma a segunda onda intitulada "regionalismo aberto". Nascido originalmente no âmbito da Cepal, a terminologia representou convergência com a ordem internacional em torno da abertura de mercados e menor participação estatal na economia (Saraiva, 2012). A criação do Mercado Comum do Sul (Mercosul) em 1991 e a tentativa de se estabelecer

4. Aqui, em um primeiro momento, a análise é mais abrangente e pauta-se sobretudo na dinâmica latino-americana. Posteriormente, a partir do debate sobre regionalismo pós-hegemônico, o foco específico passa a ser a América do Sul em si a partir dos casos da Unasul e do Prosul. 
a Área de Livre Comércio das Américas (Alca) a partir de 1994 são os dois maiores exemplos desse período em que, findado o conflito bipolar, a influência do Consenso de Washington (1989) e o avanço de medidas neoliberais principalmente privatizações e liberalizaçóes comerciais - foram fatores de grande influência nos países latino-americanos.

Já na primeira década do século XXI houve uma reviravolta nesse processo, dando margem ao surgimento da terceira onda caracterizada por "regionalismo pós-liberal" (Sanahuja, 2009; Serbin, 2010) ou "regionalismo pós-hegemônico" (Riggirozzi e Tussie, 2012). Sua ótica é focada na transformação do eixo de sustentação dos blocos regionais, passando de um viés liberal e comercial para uma agenda notadamente mais política e pautada na interferência pública do Estado. Isso se deu graças à emergência de governos de esquerda na regiáo, principalmente a partir de 2003, os quais passaram a criticar o "regionalismo aberto" em três grandes frentes: manutenção da lógica intergovernamental, ${ }^{5}$ existência de instituiçôes limitadas e integração focada na área econômico-comercial (Mariano e Ribeiro, 2016). Nesse contexto surgiram a Comunidade Sul-Americana de Naçóes (Casa), antecedente da Unasul de 2008, a Aliança Bolivariana para os Povos da Nossa América (Alba) em 2004 e a Comunidade dos Estados Latino-Americanos e Caribenhos (Celac) em 2010.

Uma das grandes e principais mudanças ocorridas nos anos 2000 foi o foco da agenda em torno da integração regional. Líderes políticos à época buscaram formas de cooperação endógena levando a agenda dos blocos ao encontro de perspectivas voltadas à infraestrutura, políticas públicas, saúde e bem-estar, finanças, defesa e segurança. Além do mais, ocorreu uma grande reorientação política contrária ao "regionalismo aberto", principalmente em torno das relaçóes hemisféricas, escapando da tutela dos Estados Unidos e se contrapondo ao sistema de regras criado em torno das instituições pan-americanas. Assim, esse regionalismo envolveu uma reorientação ideológica e geográfica considerando especificidades locais e não limitantes de ordem global (Vitelli e Milani, 2019, p. 41).

Alba, Celac e Unasul são representantes empíricos que confirmam a citação supracitada. O primeiro bloco sempre teve uma postura clara contrária à Alca; o segundo teve como auspício o diálogo de todos os países da região, excetuando-se os Estados Unidos e o Canadá; o último, representando um interesse de política externa brasileira, tentou estabelecer bases de gestão governamental endógenas que, em tese, seriam mais independentes de influências e fatores externos.

De fato, tais blocos regionais trouxeram importantes mudanças à região, principalmente em torno da aproximação entre diferentes níveis, atores e

5. Conforme será observado posteriormente nesta seção, o regionalismo pós-hegemônico não mudou a ótica intergovernamental da integração sul-americana, haja vista que blocos como a Unasul nunca apresentaram características supranacionais, ou seja, com poderes de mando além dos próprios governos nacionais. 
participantes da integraçáo. Ou seja, houve ampliação e maior dinâmica integracionista, mormente em torno da articulação e da aproximação entre Argentina e Brasil (Vázquez e Ruiz, 2009), pois ambos os países, cada um à sua maneira, procuraram vincular seus modelos econômicos com a inserção externa, dessa vez mais aparelhada ao aparato regional.

$\mathrm{O}$ grande problema não enfrentado por tais organizaçóes - e aqui se destaca a Unasul, pela qual houve o que podemos chamar de uma grande expectativa por parte de lideranças políticas, gestores e comunidades epistêmicas regionais, em virtude da criação de seus doze conselhos, além de ter sido um projeto expansível, novo, criativo e original (Nolte, 2019) - foi não ter lidado com a questão da autonomia institucional. Toma-se o caso da Unasul como mais emblemático porque, com aproximadamente dez anos de existência, ela atualmente encontra-se esvaziada e desmantelada.

Afinal, cabe questionarmos, por que isso ocorreu e como impacta o regionalismo sul-americano nos anos 2020? Para responder à primeira pergunta, temos cinco grandes fatores: multiplicidade de organizaçóes regionais, carência de maior institucionalidade atrelada à características intergovernamentais, existência de uma cultura institucional estadocêntrica, dependência em relação a potências externas e forte vínculo com agendas político-partidárias (Junqueira e Milani, 2019; Mariano e Ribeiro, 2016; Malamud, 2013; Ribeiro, 2020; Veiga e Ríos, 2007; Nolte, 2019). Somados, conformam possíveis condicionantes do enfraquecimento do "regionalismo pós-hegemônico". Posteriormente, e conforme será desenvolvido ao longo do artigo, poderemos traçar alguns breves panoramas sobre o regionalismo na próxima década.

Desde 2000, o número de novas organizaçóes regionais na América Latina superou o de outras regióes do mundo (Nolte, 2019), dando mais sustentação à chamada "sobreposição de blocos regionais", do original overlapping regionalism, que compreende casos em que Estados são afiliados a várias organizaçóes regionais simultaneamente (Ribeiro, 2020). A grande questáo é entender que a multiplicidade de blocos explica em partes o não aprofundamento da integração, denotando baixa institucionalidade. Todas as organizaçóes regionais citadas até o presente momento - com exceçáo da Comunidade Andina, substituta do Pacto Andino a partir de 1996, que possui órgão de caráter supranacional - são notadamente intergovernamentais, ou seja, capitaneadas por chefes de Estado (Santos, 2011), o que reforça um tipo de regionalismo distinto e fortalecedor das políticas centrais, segundo um modelo soberano atrelado à Westfália (Serbin, 2010). Na prática, isso significa que mesmo instâncias regionais criadas sob a luz do regionalismo pós-hegemônico não modificaram a fundo o processo de 
tomada de decisões, ficando sempre à mercê dos Poderes Executivos dos países envolvidos, principalmente presidentes e ministros.

Conectado às características aqui mencionadas, temos na América Latina uma estrutura histórica política de relação e, por vezes, dependência perante potências externas - notadamente Estados Unidos, países da União Europeia e China, os quais, em 2017 e segundo a Cepal, representavam os principais destinos das exportaçóes latino-americanas (Junqueira e Milani, 2019). A influência estadunidense na região se estabelece de longa data, remontando-se à Doutrina Monroe de 1823, à Primeira Conferência Pan-Americana em 1889, ao Corolário Roosevelt em 1904, à Política de Boa Vizinhança na década de 1930, à Diplomacia Total durante a Guerra Fria (Spykman, 1942) até chegar às políticas neoliberais nos anos 1990, tentando emplacar a Alca, projeto que se extinguiu ainda em 2005.

No início do século, e mesmo com a emergência de governos de esquerda na região, os Estados Unidos continuaram a manter suas influências, desta vez refazendo sua política hegemônica no hemisfério ocidental. O caso da OEA tornou-se emblemático nesse sentido, pois, embora tenha perdido relativamente poder de influência com a Unasul e a Celac, manteve-se, a partir de 2013, como principal instituição multilateral na regiâo e reforçou a base ideológica do país na parte sul do continente. As últimas décadas acabaram por demonstrar que, embora os Estados Unidos não intervenham diretamente nos países da região como ocorreu na Guerra Fria, isso não significa que o hemisfério tornou-se um espaço "pós-americano" (Biegon, 2017), muito pelo contrário.

A China apareceu como fator fundamental tanto por ter aumentado o interesse comercial na regiáo quanto por possuir uma política mais abrangente voltada a questôes envolvendo saúde, espaço, defesa, educação e redução da pobreza, conforme é apontado em um de seus white papers publicado em 2016 e destinado à América Latina (Junqueira e Milani, 2019). Ademais, o país está acoplado ao Fórum China-Celac, iniciativa de aumento de diálogo entre as partes com um claro viés de maior busca por autonomia face à influência norte-americana (Pini, 2015). Em virtude do aumento dessa presença chinesa, os debates centraram-se em torno de se pensar até que ponto essa influência na região era algo benéfico ou, pelo contrário, algo que suscitaria ainda mais dependência por parte dos países sul-americanos. Embora não haja uma resposta definitiva a isso, é visível que tanto a China quanto os Estados Unidos continuam a ter uma grande influência na América Latina, embora esse grau tenha que ser medido em cada país de maneira específica.

Por fim, mas não menos importante, a existência de um forte vínculo entre agendas político-partidárias domésticas e os blocos regionais é uma condicionante 
para o enfraquecimento do regionalismo pós-hegemônico. Essa afirmação condiz com outros estudos (Veiga e Ríos, 2007) ao se pensar até que ponto o grau de politização das agendas comerciais nacionais e a evolução política doméstica são variáveis de impacto no regionalismo. Aqui há três exemplos principais de explicação: a ideologização do Mercosul, a criação da Aliança do Pacífico em 2011 e a geração do Prosul em 2019 como substituto da Unasul.

$\mathrm{Na}$ década de 2010, o discurso em torno da ideologização do Mercosul adquiriu um patamar muito forte. Lideranças políticas de diversos países começaram a afirmar que o bloco regional em si tinha esse componente que freava o seu avanço em torno do estabelecimento de uma união aduaneira de fato. No Brasil, esse movimento ganhou fôlego com Michel Temer a partir de 2016 e, atualmente, figuras como o presidente Jair Bolsonaro ou o ministro da Economia Paulo Guedes reiteradamente declararam que o Mercosul precisaria entrar em uma etapa mais pragmática e menos ideológica em si. Por ideologia faz-se uma alusão direta às propostas do período do regionalismo pós-hegemônico, em que figuras como Luiz Inácio Lula da Silva, Néstor Kirchner, Pepe Mujica, Hugo Chávez, Rafael Correa e Evo Morales eram as principais lideranças políticas regionais. De modo mais recente e já em 2020, o recém-eleito presidente uruguaio, Luis Alberto Lacalle Pou, reiterou o mesmo tipo de discurso, ${ }^{6}$ iniciando um governo de viés mais à direita no país, se comparado com seu antecessor, Tabaré Vázquez (Costa, 2019).

Em seguida, a criação da Aliança do Pacífico, bloco formado por Chile, Colômbia, Costa Rica, México e Peru, pode ser elencada como um dos primórdios do enfraquecimento desse regionalismo pós-hegemônico por demonstrar, já no início da década, o retorno de um projeto regional de viés mais liberal. Voltado aos países do Pacífico, a Aliança do Pacífico tem como diretrizes centrais a abertura econômica, especialização e utilização do comércio como provedor de divisas e regulador de preços (Paikin e Perrotta, 2016), além de possuir claramente uma menor institucionalização se comparado, por exemplo, ao próprio Mercosul. Essa constatação se dá justamente com a maior influência chinesa na região, conforme sustentado anteriormente.

Agora, de modo mais recente, o já citado desmantelamento da Unasul e sua substituição pelo Prosul parece colocar, pelo menos no curto prazo, reticências quanto ao futuro do regionalismo sul-americano na década de 2020. O foro denota o forte vínculo político-partidário existente entre mudanças de cunho doméstico nos países e os rumos do regionalismo. Se, para a criação da Unasul, houve convergência entre líderes e presidentes durante a "Onda Rosa", atualmente o Prosul denota o

6. Mais informações disponíveis em: <https://www.elpais.com.uy/informacion/politica/lacalle-pou-mercosur-uruguayhay-aflojarle-corset.html>. Acesso em: 22 abr. 2020. 
mesmo movimento, alinhado mais à direita e com estrutura flexível, ou seja, sem envolver muitos custos financeiros aos Estados intrincados no processo.

A par de todas as alteraçóes pontuadas, o fim da Unasul e sua relativa substituição pelo Prosul parece ser mais um capítulo de enfraquecimento da região. Embora possamos afirmar que ambos representam interesses políticos específicos, o foro é muito mais precário institucionalmente, sendo por ora mais viável denominá-lo de espaço de diálogo do que bloco regional em si. O regionalismo sul-americano para a década de 2020 ficará marcado, inicialmente, por uma zona cinza de grande incerteza e de fragilização da coesão regional (Neves e Honório, 2019).

Em meio às dúvidas, há uma tendência de esse novo tipo de regionalismo de relativa retomada do liberalismo e atrelado à guinada governamental à direita - não apresentar sustentabilidade duradoura. Isso porque há uma série de instabilidades políticas na América do Sul e o papel do Brasil nesse sentido será fundamental, pois o país se encontra cada vez mais isolado e distante do papel de liderança regional por ele até então assumida (Caetano, López Burian e Luján, 2019).

\section{OS MOVIMENTOS DE INSTABILIDADE NOS PAÍSES SUL-AMERICANOS}

As mudanças políticas na América do Sul são refletidas não somente no desmantelamento das instituiçóes regionais construídas nos últimos vinte anos, tal qual discutido na seção anterior, como também no âmbito nacional, marcado por protestos, manifestaçóes, marchas e levantes sociais em suas diferentes insatisfaçóes e demandas. $\mathrm{O}$ aprofundamento das problemáticas nacionais ao longo dos anos 2010 acabaram por irromper em 2019 em inúmeros protestos nacionais na América Latina, a começar por protestos de grande impacto na Venezuela em janeiro, no Brasil nos meses de maio a junho, seguido de levantes de outubro a dezembro na Bolívia, no Chile, na Colômbia, no Equador e no Peru. Ao longo desta seção discutiremos um pouco sobre alguns desses movimentos de instabilidade, os quais tiveram um impacto de grande escala para as relações regionais.

\subsection{Venezuela}

A reeleição de Nicolás Maduro na Venezuela em 20 de maio de 2018 foi marcada por denúncias de fraudes e uma abstenção de mais de $50 \%$ dos eleitores. ${ }^{7}$ Por sua vez, o não reconhecimento do governo e das eleiçóes por catorze países americanos ampliava já no período a crescente fragmentação do espaço regional

7. Disponível em: <https://brasil.elpais.com/brasil/2018/05/20/internacional/1526840397_319633.html>.Acesso em: 13 abr. 2020. 
construído. ${ }^{8}$ Entre os países críticos se encontravam aqueles que fazem parte do Grupo de Lima. ${ }^{9}$

Diante do aprofundamento da instabilidade nacional venezuelana pós-eleições e a consequente posse de Nicolás Maduro em 10 de janeiro de 2019, o entáo presidente da Assembleia Nacional, Juan Guaidó, no dia 23 do mesmo mês, se autodeclarou presidente interino da Venezuela, ${ }^{10}$ contando com o apoio de milhares de pessoas que foram às ruas em Caracas em uma das maiores manifestaçôes contra o governo desde 2017. ${ }^{11}$

Após sua declaração, Guaidó recebeu apoio da OEA, dos Estados Unidos, do Canadá, e de vários outros países latino-americanos, entre eles Argentina, Brasil, Colômbia, Chile, Equador, Paraguai, e Peru. Alguns países como o Uruguai se mantiveram neutros e outros como Bolívia e México declararam seu apoio a Maduro. ${ }^{12}$ Partindo da observação da atuação dos mecanismos regionais diante da situação venezuelana, a Unasul, já em desintegração, não fez declarações e a OEA, a partir de seu conselho permanente, aprovou uma resolução para deixar de reconhecer o entâo representante venezuelano na organização Asbina Marín Sevilla, para reconhecer Gustavo Tarre Briceño, representante nomeado por Juan Guaidó. ${ }^{13}$

Várias foram as consequências do estreitamento da conjuntura crítica instaurada na regiáo, passando por manifestaçôes de apoiadores do chavismo à convocação da oposição para protestos contra o governo de Maduro. A OEA e o Observatório Venezuelano de Conflictividad Social apontaram que do dia 21 a 24 de janeiro já se contavam 16 mortos e 278 presos por conta dos levantes sociais. ${ }^{14}$ Ademais das manifestaçóes populares, as semanas seguintes no país foram marcadas por seguidos apagóes de grandes dimensóes devido a falhas elétricas na usina de Guri. ${ }^{15}$

8. Disponivel em: <https://brasil.elpais.com/brasil/2018/05/21/internacional/1526898417_522539.html>. Acesso em: 13 abr. 2020.

9. Criado em agosto de 2017, o Grupo de Lima se conformou como um mecanismo ad hoc (Sanahuja, 2019) para atuar no curto prazo com o objetivo de projetar-se como uma instância multilateral informal para responder a ausência de ações ante os problemas nacionais venezuelanos (Barros e Gonçalves, 2019).

10.Maisinformações disponíveisem:<https://brasil.elpais.com/brasil/2019/02/06/internacional/1549460663_954127. html>. Acesso em: 14 abr. 2020.

11.Maisinformações disponiveisem:<https://brasil.elpais.com/brasil/2019/01/23/internacional/1548249429_996363. html>. Acesso em: 14 abr. 2020.

12. Mais informações disponiveis em: <https://g1.globo.com/mundo/noticia/2019/01/23/juan-guaido-prestajuramento-como-presidente-interino-da-venezuela.ghtml>. Acesso em: 14 abr. 2020.

13. Mais informações disponíveis em: <https://oglobo.globo.com/mundo/oea-reconhece-nomeado-por-guaido-comorepresentante-da-venezuela-23586231>. Acesso em: 14 abr. 2020.

14. Mais informações disponíveis em: <https://www.elpais.com.uy/informacion/politica/lacalle-pou-mercosururuguay-hay-aflojarle-corset.html>. Acesso em: 22 abr. 2020.

15. Mais informações disponíveis em: <https://tinyurl.com/y3e3obls>. Acesso em: 14 abr. 2020. 
A crise nacional e a fragilidade da infraestrutura venezuelana afetam não somente sua população como os países ao seu redor, seja a partir de colapsos energéticos como também da ampliação dos fluxos migratórios. A Organização das Naçôes Unidas (ONU) e a Humans Rights Watch (HRW) apontam que de 2014 a 2017 mais de 2,3 milhóes de venezuelanos deixaram a Venezuela, sendo os principais países de destino: Colômbia, Peru, Equador, Chile, Argentina, Estados Unidos, Panamá, Brasil, México, países do sul do Caribe e República Dominicana. A crise migratória se apresenta como mais um fator crítico diante da crescente instabilidade na América do Sul, se conformando como uma crise de dimensão regional (Mijares e Rojas Silva, 2018).

Ainda assim, até setembro de 2018, os países da região encontravam, através das instituiçôes regionais, um aparato para criar medidas em busca de garantir aos venezuelanos permissões legais de residência. "Por exemplo, (...) a Argentina e o Uruguai permitem que os venezuelanos solicitem um visto especial aplicável a nacionais do Mercosul (...) e venezuelanos no Equador podem solicitar um visto ligado à Unasul para permanência” (HRW, 2018).

Entretanto, o aprofundamento das divergências nacionais em meio às fragilidades das instituiçóes regionais, em especial à Unasul, resultaram na perda desse espaço para resoluçáo dos problemas venezuelanos. De acordo com Mijares e Ramírez (2020), um dos fatores de deslegitimação e desmantelamento da Unasul em 2019, causando a retirada dos países do bloco, foi o náo reconhecimento da legitimidade do governo de Maduro, principalmente após as eleiçóes de 2018. Por sua vez, essa fratura política paralisa a região, não somente ao não encontrar no Grupo de Lima um ator que possa exercer um papel relevante na resoluçáo da crise venezuelana (Sanahuja, 2019), mas também por paralisar espaços de diálogos que até então tinham a capacidade de reunir os governos da região.

\subsection{Brasil}

Ao longo dos anos 2000, o governo brasileiro foi o principal instigador dos processos de integração e cooperação regional na América do Sul, tendo um papel de suma importância na criação da Casa e posteriormente da Unasul. Ademais, no mesmo período, o Brasil, por meio do Banco Nacional de Desenvolvimento Econômico e Social (BNDES), pôde financiar empresas brasileiras para realizar obras de infraestrutura em diferentes países do sub-continente, sendo um importante ator no desenvolvimento da infraestrutura regional (Alem e Cavalcanti, 2005; Honório, 2013; Neves, 2019; Saraiva, 2011).

Mudanças e instabilidades nacionais afetam diretamente o papel de liderança que o Brasil tem nas instituiçōes regionais. A evolução da problemática brasileira - assim como o avanço da Operação Lava Jato, que resultou na 
instabilidade nacional que em 2016 levou ao impeachment da então presidenta Dilma Rousseff e à ascensão de seu vice, Michel Temer - refletiu no fim dos financiamentos a obras de infraestrutura por parte do BNDES (Barrenengoa, 2019; Honório, 2019; Neves, 2019). De 2016 até 2019 não houve nenhum aporte financeiro a empresas brasileiras para novas obras de infraestrutura nos países sul-americanos (Saraiva e Velasco Júnior, 2016), resultando em um cenário regional nada favorável.

A crise nacional, portanto, colocou em xeque a capacidade do país de manter a liderança dos processos regionais. A instabilidade política e econômica no país resultou em uma crise institucional que diminuiu "sensivelmente a previsibilidade política brasileira" (Fuccille et al., 2017, p. 48).

Com o aprofundamento da crise venezuelana, o Brasil seguiu os outros países da região ao denunciar a carta constitutiva da Unasul no dia 15 de abril de 2019 (Brasil, 2019), deixando para trás o papel de liderança regional que havia consolidado por meio da instituiçáo. Ainda assim, as demandas sociais ganhavam maiores dimensóes, afastando do espectro político a discussão da importância das relaçôes regionais para o país.

No dia 15 de maio, milhares de pessoas nos 26 estados do país foram às ruas para se manifestar contra os cortes do Ministério da Educação. ${ }^{16}$ Em 2019, o governo brasileiro gastava $6 \%$ do seu produto interno bruto (PIB) em educação. Apesar de esse valor ser apenas um terço da média estabelecida pela Organização para a Cooperação e Desenvolvimento Econômico (OCDE), desde janeiro o Ministério da Educação vinha realizando mais cortes nas verbas das universidades públicas, tendo cancelado no final de abril mais de 3 mil bolsas de pesquisa. ${ }^{17}$

Com o congelamento de mais de $\mathrm{R} \$ 7$ bilhôes "em todos os níveis educativos, incluindo o não repasse de $30 \%$ do orçamento não obrigatório das instituiçôes de ensino superior", diferentes setores se mobilizaram. ${ }^{18}$ Diante das insatisfaçôes nacionais, o debate do âmbito regional estava ainda mais distante, como pôde ser visto após a saída do país da Unasul, uma vez que o governo brasileiro, que antes liderava os projetos regionais, não sugeriu a criação de um novo espaço, mas se uniu à ideia de criação do Prosul lançada pelo presidente Iván Duque, da Colômbia, em conjunto com o presidente chileno Sebastián Pińera (Tokatlian, 2019).

16. Mais informações disponíveis em: <https://brasil.elpais.com/brasil/2019/05/15/politica/1557950158_551237. html>. Acesso em: 15 abr. 2020.

17. Mais informações disponíveis em: <https://brasil.elpais.com/brasil/2019/05/11/politica/1557603454_146732. html>. Acesso em: 15 abr. 2020.

18. Disponivel em: <https://brasil.elpais.com/brasil/2019/05/14/politica/1557853974_560498.html>. Acesso em: 15 abr. 2020. 


\subsection{Bolívia}

Após perder um referendo popular que habilitaria a sua terceira reeleição em 21 de fevereiro de 2016, Evo Morales vinha enfrentando certa resistência popular. Ainda assim, contrário àqueles que votaram "não" no referendo realizado em 2017, o Tribunal Constitucional Plurinacional (TCP) posicionou-se favoravelmente a um recurso abstrato de inconstitucionalidade contra a limitante constitucional de mandatos consecutivos apresentado pelo Movimento Al Socialismo (MAS), partido do entáo presidente, declarando inconstitucionais os artigos "das leis eleitorais bolivianas que limitavam a quantidade de períodos contínuos que pode ter qualquer autoridade boliviana elegida por voto popular". ${ }^{19}$

Apesar da crescente instabilidade nacional e da desconfiança popular do governo interino, no final de maio de 2019 Evo Morales deu início a sua campanha eleitoral buscando seu quarto mandato. Grande parte da desafeiçáo pela possibilidade de reeleição de Evo Morales refletiu "uma percepção estendida da corrupçáo, um desejo das classes médias tradicionais em retomar seu local de predominância do qual foram retirados desde 2006 e a manobra realizada pelo presidente para habilitar sua candidatura no ano apesar da proibiçáo constitucional". ${ }^{20}$

A percepção acerca da corrupçáo se deu também pelo andamento da Operação Lava Jato no Brasil, que acabou por levantar suspeitas e dar início a investigaçóes sobre subornos realizados pelas empresas brasileiras Odebrecht e Camargo Corrêa a funcionários do governo boliviano (Honório, 2019). Ademais, a Polícia Federal brasileira interceptou mensagens eletrônicas que revelam atos de corrupção de mais de US\$ 4 milhóes nos governos de Veltzé e no começo do governo de Evo Morales. Dados mais recentes ainda estão sendo analisados pelas comissóes para conferir outras 179 suspeitas de participação nos subornos. ${ }^{21}$

Sendo assim, o desgaste do governo de Evo foi evoluindo até seu estopim, após sua reeleição pelo quarto mandato, no dia 20 de outubro de 2019. Marcada também por denúncias de fraudes e inconsistências, a vitória de Morales resultou em um conflito contínuo entre grupos de manifestantes contrários e favoráveis ao resultado eleitoral, sendo que até o dia 8 de novembro já haviam sido registradas três mortes e dezenas de feridos. ${ }^{22}$

19. Tradução nossa. Disponível em: <https://www.bbc.com/mundo/noticias-america-latina-42159445>. Acesso em: 15 abr. 2020.

20. Disponivel em: <https://elpais.com/internacional/2019/05/26/actualidad/1558822382_298328.html>. Acesso em: 15 abr. 2020.

21. Mais informações disponíveis em: <https://eldeber.com.bo/septimo-dia/los-mas-de-80-viajes-a-bolivia-de-dosempresarios-del-escandalo-lava-jato_21741>.

22.Maisinformações disponíveisem:<https://brasil.elpais.com/brasil/2019/11/07/internacional/1573143420_294513. html>. Acesso em: 20 abr. 2020. 
Diante dos levantes sociais e do aprofundamento da instabilidade no país, a OEA realizou uma auditoria eleitoral que logo após as eleiçôes resultou positivamente para a existência de açóes deliberadas que buscaram manipular os resultados eleitorais, entre eles a paralisação intencional e arbitrária do Sistema de Transmissão de Resultados Preliminares (TREP); a introdução de servidores não previstos que desviaram de maneira intencional o fluxo de informaçóes do TREP; e irregularidades no preenchimento de atas e seu cômputo" (OEA, 2019).

A pressão resultante da verificação das fraudes e a exigência de novas eleições ampliaram os levantes e conflitos sociais, ${ }^{23}$ levando à renúncia de Evo Morales em 10 de novembro, que, por sua vez, precipitou uma convulsão social. Horas antes da renúncia, as forças armadas do país já estavam nas ruas a fim de conter os protestos a favor do governo. ${ }^{24} \mathrm{~A}$ saída de Morales do país e seu refúgio no México insuflaram na regiáo uma instabilidade política ainda maior, principalmente para a Unasul, visto que após a renúncia de Evo o governo interino anunciou sua saída do organismo em 10 de março de $2020 .{ }^{25}$

\subsection{Chile}

Apesar de demonstrar uma crescente atuação na regiáo ao ter sido um dos primeiros países a deixar à Unasul, além de propor a criação do Prosul, sendo o país com o maior número de acordos bilaterais de livre comércio do mundo, visto por muitos como exemplo de êxito econômico, ${ }^{26}$ o Chile também passou por turbulências populares no final de 2019.

No início de outubro, o presidente Sebastián Piñera decretou o aumento de $3,75 \%$ do preço da passagem de metrô em Santiago, o que resultou de imediato em massivos protestos pela capital, culminando em mais de 23 mortes e milhares de chilenos detidos. ${ }^{27}$

Diante do descontentamento generalizado, Piñera anunciou logo em seguida, no dia 19 de outubro, a suspensão do aumento do valor do metrô, decretando toque de recolher na capital. Ainda assim, o problema chileno se revelou muito maior diante dos saques, da violência e da reação desmedida por parte dos militares. As reivindicaçóes do povo chileno buscavam justiça social no país, refletindo as limitaçóes do modelo privatizador dos serviços públicos

\footnotetext{
23. Mais informações disponíveis em: <https://www1.folha.uol.com.br/mundo/2019/11/apos-auditoria-oea-diz-queeleicao-na-bolivia-foi-fraudulenta-e-pede-novo-pleito.shtml>. Acesso em: 16 abr. 2020.

24.Maisinformações disponíveisem:<https://brasil.elpais.com/brasil/2019/11/12/internacional/1573522447_900675. html>. Acesso em: 16 abr. 2020.

25. Mais informações disponíveis em: <https://agenciabrasil.ebc.com.br/internacional/noticia/2020-03/uruguai-deixaunasul-e-cancela-saida-do-tiar>. Acesso em: 20 abr. 2020.

26. Mais informações disponíveis em: <https://brasil.elpais.com/brasil/2019/11/09/economia/1573308911_971311. html>. Acesso em: 16 abr. 2020.

27. Mais informações disponíveis em: <https://tinyurl.com/yZayym7t>. Acesso em: 16 abr. 2020.
} 
instaurados conjuntamente à constituição do país elaborada ainda durante o período ditatorial de Augusto Pinochet.

Por sua vez, as instabilidades populares desvelaram na América Latina, de acordo com Panizza em entrevista, as fragilidades dos mecanismos de representação política, tais como "percepções de que os governos beneficiam poucos, e não a maioria da população; serviços públicos de má qualidade; altos níveis de corrupção; e quase nenhuma confiança nas instituições". ${ }^{28}$ Ainda de acordo com Panizza, há patologias políticas e sociais que despertam a instabilidade nos países latino-americanos, cujos níveis de desigualdade e pouco crescimento econômico recente se apresentam como um dos fatores para o mal-estar político atual, uma vez que os governos têm baixa "capacidade de processar demandas sociais legítimas, além da falta de mecanismos institucionais de participação política". ${ }^{29}$

\subsection{Equador}

Cada protesto nacional que marcou os países sul-americanos reflete um mal-estar social, produto das desigualdades e de como cada governo tem lidado com elas. Por sua vez, a origem dos descontentamentos e o grau de violência aplicado em sua contenção refletem também como o Estado trata a sociedade ante a necessidade de reestabilizá-la política e economicamente. Os levantes sociais equatorianos se originaram dos problemas nacionais e das respostas governamentais, porém, se assemelhando aos processos até então mencionados na medida em "(...) que coincide na lógica de relação entre o Estado, os setores produtivos e os setores sociais, e que tem repercussōes regionais" (Levi, 2020, p. 58, tradução nossa).

O ápice das movimentaçóes sociais no país se deu a partir de setembro de 2019 após o então presidente equatoriano, Lenin Moreno, indicar medidas de corte do gasto público que recairiam diretamente no fim do subsídio à gasolina e ao diesel, assim como em um aumento de impostos aos produtos de consumo da população, como o Imposto de Valor Agregado (IVA) de 12\% a 15\%. Ao implementar o Decreto Executivo no 883 em 1o de outubro, o preço dos combustíveis subiu, havendo de imediato reações do setor de transportes, visto que o aumento de custos recairia sobre produtos e tarifas de transporte da população. A não negociação das medidas e sua não implementação gradual se constituíram faltas graves a uma população já insatisfeita, reunindo representantes de grupos indígenas, trabalhadores, partidos políticos e outros atores (Levi, 2020).

28. Mais informações disponíveis em: <https://www.em.com.br/app/noticia/internacional/2019/11/03/interna _ internacional, 1098025/entenda-o-que-explica-a-onda-de-manifestacoes-na-america-do-sul.shtml>. Acesso em: 16 abr. 2020.

29. Mais informações disponíveis em: <https://www.em.com.br/app/noticia/internacional/2019/11/03/interna_ internacional, 1098025/entenda-o-que-explica-a-onda-de-manifestacoes-na-america-do-sul.shtml>. Acesso em: 16 abr. 2020 . 
Refletindo novamente uma semelhança na resposta à crise, Valdivieso (2019) aponta a crítica utilização da violência como mecanismo de controle durante as manifestaçôes, seja através da força física, como também através da violência discursiva em declarações ofensivas de representantes do governo. O uso da força teve início com "o decreto do estado de exceção, no dia 3 de outubro, antecipando-se Moreno ao acirramento das manifestações" e, por sua vez, os discursos oficiais em tom de ofensa aos grupos indígenas, que "visavam desprestigiar e reduzir o chamamento da população, acirrou os ânimos dos manifestantes, tornando os protestos mais agudos" (Valdivieso, 2019).

Um dos aspectos mais afetados durante as instabilidades que movimentaram 2019 foi a democracia. Assim como ela é uma variável de suma importância para o desenvolvimento nacional e para o cumprimento dos direitos da populaçáo, também se apresenta como condição necessária para a integração regional (Malamud e Schmitter, 2007).

A falta de legitimidade das instituiçóes democráticas em consequência da falta de equidade por um longo período converteu a América do Sul em um "caldeirão onde a raiva e a frustração se cozinharam sem que o vapor encontrasse uma via de escape por estarem as instituições obstruídas em seus privilégios e falta de renovação. O calor de direcionou entáo para fora do sistema, às ruas" (Malamud, 2020, p. 6, tradução nossa).

Por fim, após refletir brevemente sobre os principais movimentos causadores de instabilidade nos países sul-americanos na atualidade, é possível compreender que a conjuntura interna reflete-se no posicionamento externo desses países, assim como nas suas relaçóes cooperativas na América do Sul. A longo prazo, isso pode representar uma grande perda do que se alcançou até então. Afinal, há espaço para discussão do âmbito regional em um cenário nacional tão fragmentado e polarizado?

\section{A POLÍTICA EXTERNA BRASILEIRA E O ENFRAQUECIMENTO DO VÍNCULO SUL-AMERICANO}

O panorama de instabilidade e fragmentação do regionalismo sul-americano dos últimos anos guarda relaçáo com uma multiplicidade de fatores resultantes das decisões levadas a cabo nas unidades nacionais. O transbordamento subcontinental da crise venezuelana, manifestado na crise migratória e na escalada do conflito diplomático com a Venezuela, é um elemento crucial para a compreender as reaçóes desencadeadas no âmbito da política externa desses países. Tanto o rechaço coletivo ao presidente Nicolás Maduro, e o consequente aceno ao oposicionista venezuelano Juan Guaidó, quanto a articulação de uma nova frente de países para 
gestão do conflito, o Grupo de Lima, são manifestaçôes que refletiram essa nova configuração de poder na América do Sul.

Diante desse pressuposto, devemos considerar o papel do Brasil enquanto um dos atores-chave na compreensão dessa conjuntura. Durante a primeira década do século XXI, o país influiu decisivamente nas iniciativas de arquitetura regional - seja no desenho institucional da Unasul e de sua predecessora, a Casa, seja na remodelagem do Mercosul e na capacidade de agir enquanto paymaster regional, vinculando ainda o BNDES aos empreendimentos de sua projeção regional (Malamud e Gardini, 2012).

Os anos 2010, no entanto, apresentaram um cenário adverso em relação ao país. A capacidade de manter um ativismo diplomático e o comprometimento com as pautas de escopo regional ofereceram indícios de esgotamento já na metade da década. Entre 2013 e 2014, o fim do ciclo das commodities, no cenário internacional, e a políticas macroeconômicas equivocadas no cenário nacional resultaram em um cenário de instabilidade econômica (Carvalho, 2018). Na arena doméstica, a grave retração econômica e a ocorrência de megaoperaçóes de combate à corrupção limitaram a participação de grandes grupos empresariais que tanto caracterizaram a presença mais ativa do Brasil na vizinhança até então (Cries, 2016).

No cenário pós-impeachment, o Brasil passou a encampar, a partir da segunda metade de 2016, um conjunto de açóes que esvaziaram os espaços de interlocuçáo com o regionalismo pós-hegemônico, sob o slogan da "desideologizaçâo" da política externa. Embora a gestão Temer tenha propiciado avanços pontuais no âmbito do Mercosul, a diplomacia brasileira do período, de modo geral, afastou o país da liderança das grandes pautas regionais. Mesmo os eventos cruciais que apontam para a sobrevida do regionalismo - a conclusão das negociaçóes de longa data do acordo Mercosul-União Europeia e a criação do Prosul - ocorreram por energia política de países como Argentina e Colômbia.

Diante da conjuntura, devemos verificar na atuaçáo do Brasil os elementos que sugerem o enfraquecimento da América do Sul na política externa brasileira e que acabam por impactar o quadro geral de esmorecimento do regionalismo. Argumenta-se que o enfraquecimento da vertente sul-americana na estratégia de inserção internacional do Brasil está relacionado também a fatores endógenos ao país, que podem ser sintetizados em dois momentos: $i$ ) uma mudança de ênfase na opção sul-americana, ainda no governo Rousseff, e que ganha aspectos decisivos com a ascensão de uma plataforma política, na gestáo Temer, que antagoniza com as organizaçóes de cunho pós-liberal e pós-hegemônico, a fim de redirecionar alguns elementos da atuação brasileira no espaço regional; e ii) uma mudança de caráter programático ainda em curso, no governo Bolsonaro, que evidencia 
uma noção de ruptura mais radical de conduta em relação à América do Sul, como parte de um projeto de redefinição geral da inserção internacional do país com base em amplo questionamento dos baluartes da tradiçấo da política externa brasileira.

\subsection{Transições na ênfase de América do Sul: redefinição de prioridades e o esvaziamento do regionalismo pós-hegemônico}

A despeito de as Relaçóes Exteriores do governo de Michel Temer, chefiadas pelos ministros das Relaçóes Exteriores José Serra e Aloysio Nunes, marcarem um ponto de deflexão importante no regionalismo sul-americano, os desgastes na priorização da América do Sul possuem raízes anteriores, identificadas ainda nos anos do governo Dilma Rousseff. Esses movimentos decorrem tanto do crescente descomprometimento da mandatária no tocante às pautas externas como do enfraquecimento do potencial de vocalizaçáo dos interesses regionais por parte do Itamaraty (Cervo e Lessa, 2014; Saraiva, 2016; Souza, 2018).

Os chanceleres que sucederam Antônio Patriota a partir de 2013, Luiz Alberto Figueiredo (2013-2015) e Mauro Vieira (2015-2016), encerraram suas participaçōes demonstrando um perfil de baixa identificação com as pautas sul-americanas em detrimento de uma sintonia com a atuação no BRICS (Brasil, Rússia, Índia, China e África do Sul). O forte contingenciamento de gastos do Itamaraty implicou diminuição significativa de seu orçamento e contribuiu para uma situação de "sucateamento" do órgão (Saraiva, 2016). Durante o governo Rousseff, a desconexão entre a chefe de Estado e o Itamaraty atingiu um nível de "paroxismo" que impactou na formulação da política externa (Lopes e Burian, 2018), incluindo toda a cadeia de comando dos temas afeitos à América do Sul e a Unasul.

Nos últimos anos de governo da mandatária, o Planalto demonstrou abrir mão dos compromissos que caracterizavam a capacidade de iniciativa externa da década anterior. O país se tornou devedor de organismos internacionais na ordem total de R \$ 1 bilhão, e presenciou, no escopo regional, a diminuição de recursos humanos destinados à Coordenadoria-Geral da Unasul, a divisão do Itamaraty que administra os assuntos do bloco (Souza, 2018). De grande incentivador a principal devedor dos aportes anuais na Unasul, o país também deixou de ser uma presença constante em encontros de alto nível e nas reuniôes setoriais do bloco. A conclusão é de que a gestão Rousseff náo contribuiu para a institucionalidade da organismo sul-americano, tornando mais evidente a dependência das organizaçóes regionais às instituiçōes nacionais (Fuccille et al., 2017).

A despeito dessas ambivalências, o Brasil manteve, até meados de 2016, a continuidade do discurso favorável ao regionalismo sul-americano e em defesa de 
organizações como Unasul, Celac e o Mercosul ampliado. Em contrapartida, esses produtos regionais passaram a ser objeto central de críticas da gestão do presidente Temer, que buscou desvencilhar a imagem do governo de resquícios de herança do ciclo petista no poder, apostando na priorização dos processos regionais de lógica comercialista e na ênfase do país em sua inclinação globalista e asiática.

O programa Uma Ponte para o Futuro (2015), espécie de guia das ações governamentais da gestão Temer, preconiza a forma pela qual a América do Sul seria conjugada aos interesses brasileiros: a partir da "volta às origens" do Mercosul, que pressupõe a constituição de uma área de livre comércio, e do impulsionamento da inserção da economia brasileira em áreas econômicas relevantes, tais como Estados Unidos, União Europeia e Ásia (PMDB, 2015). $\mathrm{O}$ fato inovador é que ficaram ausentes outros modos potenciais de atuação do entorno estratégico brasileiro, a exemplo dos empreendimentos da última década, o que ampliou o leque de cooperação para as áreas de infraestrutura, defesa, educação, energia, entre outros.

A brevidade da gestáo Temer não a impediu de ser decisiva para os rumos que o regionalismo assumira desde então. No início do governo, havia uma elevação do tom diplomático da chancelaria com os países vizinhos que se mostraram críticos à destituição da ex-presidente, caso principalmente da Venezuela e da Bolívia, o que tendeu ao estremecimento diplomático com o presidente Nicolás Maduro a partir de então. Tanto Serra quanto Nunes encamparam um movimento de isolacionismo regional da Venezuela que resultou em sua suspensão do Mercosul. ${ }^{30}$ A leitura feita pelos agentes políticos brasileiros naquele momento é de que a crise social, econômica e política do povo venezuelano estaria necessariamente atrelada às reformas chavistas reconduzidas "despoticamente" pelo regime de Maduro (Barros e Gonçalves, 2019).

Houve, portanto, um movimento dúbio da gestão Temer no tocante à ênfase conferida ao regionalismo. Ao mesmo tempo que se teve o abandono de uma visão mais ampliada de América do Sul, cristalizada na rejeição à Unasul, optou-se por uma preocupaçáo com o resgate do Cone Sul, representado pelo Mercosul. No âmbito deste último, o governo Temer eliminou mais de setenta barreiras ao comércio intrabloco, desenvolveu negociaçóes com Canadá, Singapura e Coreia do Sul, além de ter retomado as negociaçóes do Acordo Mercosul-União Europeia.

Ou seja, o que houve foi a realocação, ainda que assimétrica, do ativismo diplomático de uma frente para a outra, no grande guarda-chuva que é a inserção internacional do país. Diante disso, a rejeição brasileira a uma postura mais proativa diante da crise venezuelana e aos custos de uma associação mais abrangente com o

30. Disponível em: <https://www1.folha.uol.com.br/poder/2018/12/temer-reviveu-itamaraty-apos-apagaodiplomatico-de-dilma.shtml>. 
entorno regional deve ser lida dentro de um contexto de redefinição de prioridades brasileiras. Essas prioridades se expressaram na faceta interna a partir de medidas empreendidas pela chancelaria no sentido de restabelecer o lugar do Itamaraty e promover o saneamento das dívidas das gestôes anteriores e o planejamento estratégico de gestão a médio e longo prazo.

No Mercosul, a mudança de postura representada pelo governo Temer encontrou convergência com os objetivos da Argentina de Maurício Macri. A consonância do discurso econômico neoliberal por parte de ambos os governos abriu espaço para a revitalização das discussóes de cunho comercial. É a partir de 2017 que o Brasil passa a pleitear sua entrada na OCDE. Em contrapartida, houve retração nas pautas sociais do bloco, refletida na extinção da figura do Alto Representante-Geral do Mercosul (ARGM), órgáo estratégico criado em 2010 para impulsionar os consensos entre os países-membros, principalmente, na dimensão social do Mercosul.

Durante sua existência, a função foi ocupada por três brasileiros. O embaixador e ex-secretário-geral das Relaçôes Exteriores Samuel Pinheiro Guimarães foi designado ao cargo desde o início, em janeiro de 2011, até a data de sua renúncia, em junho de 2012, motivada pela falta de compromisso dos países com os projetos de cunho social no interior do bloco (Souza, 2018). A partir de então, estiveram à frente do ARGM o economista e ex-secretário executivo do Ministério do Desenvolvimento, Indústria e Comércio, Ivan Ramalho, entre junho de 2012 e fevereiro de 2015, e o ex-deputado federal (Partido dos Trabalhadores - PT) Florisvaldo Fier, atuante de então até a extinção do cargo, em janeiro de 2017, por decisão do Conselho do Mercado Comum.

Ademais, durante a gestão Temer, são observadas na estrutura do Itamaraty dinâmicas de enfraquecimento dos âmbitos institucionais ligados à América do Sul e à integração regional. Com a diluição da Subsecretaria-Geral de América do Sul, os temas de América do Sul, integração regional e Mercosul foram relegados a quatro departamentos específicos dentro da Subsecretaria-Geral da América Latina e do Caribe. ${ }^{31}$

Já o processo de esvaziamento da Unasul, que vai desde as manifestações pontuais de descontentamento até a marcante deserção da maioria dos países do bloco, conta ainda com o evento decisivo da crise venezuelana e sua condução por parte da coalizaçấo liderada pelo Itamaraty. A opçâo de Nunes em levar a discussão da crise venezuelana para o âmbito da OEA e a recusa de tratá-la, inicialmente, no escopo intrarregional, sinalizaram a preferência brasileira pelos

31. Trata-se dos departamentos que constam do Decreto № 8.817, de 21 de julho de 2016: Departamento da América do Sul Meridional; Departamento da América do Sul Setentrional e Ocidental; Departamento de Integração Econômica Regional; e Departamento do Mercosul. 
instrumentos hemisféricos de concertação. Em um segundo momento, despontou como articulação preponderante no trato da crise venezuelana o Grupo de Lima, elemento que reforçou tanto a ênfase do Brasil em mecanismos ad hoc, em despeito dos espaços mais institucionalizados, quanto a preferência por espaços dos quais o pivô da crise, o governo do presidente Nicolás Maduro, não tem interlocução.

Até 2015, o Brasil vinha privilegiando o espaço institucional da Unasul para a gestão de conflitos transnacionais, sendo acionado em diversas ocasióes entre 2008 e 2015, entre os quais se destacam: a crise de Pando em 2008; a escalada de tensão entre Colômbia e Venezuela em 2009; e a destituição do ex-presidente Fernando Lugo no Paraguai em 2012. É no âmbito da OEA que o governo Temer buscou restaurar, embora sem sucesso, o Grupo de Países Amigos da Venezuela espécie de pacto entre países análogo ao criado em 2003 e que evitou um golpe de Estado no país bolivariano.

Por conseguinte, o cenário da política externa em que o governo Bolsonaro ascende tem como pressuposto duas mudanças fundamentais nas relaçóes do Brasil com a América do Sul: uma faceta doméstica, de gestão interna, centrada na correção de rumos do governo anterior, que permitiu saneamento financeiro, repactuação de compromissos protocolares com organismos internacionais e realocação institucional do Ministério das Relaçóes Exteriores; e uma faceta exterior, de projeçáo internacional, cuja recusa às instâncias do regionalismo pós-hegemônico não produz efeitos de um protagonismo equiparável em quaisquer outras frentes de atuação regional desde então.

\subsection{Transições programáticas de América do Sul: indícios de realinhamento externo e vácuo de liderança regional}

A chegada de Jair Bolsonaro à presidência ocorreu em um cenário de incertezas quanto às prioridades para a regiâo sul-americana e a definiçấo dos rumos estratégicos gerais da política externa do governo. Essa percepção é oriunda de dois fatores principais: tanto pela aridez de exposiçóes programáticas que marcou a campanha do entáo candidato do Partido Social Liberal (PSL), dada a ausência nos debates eleitorais, quanto pela forma bastante simplificada com que o tema das relaçóes exteriores esteve diluído no seu plano de governo. Dos quinze pontos que guiam os eixos prioritários do plano de governo "O Caminho da Prosperidade", nenhum deles é destinado às açóes exteriores do país ou desenvolve objetivos claros e meio de atingi-los no campo internacional (Souza e Telarolli, 2018).

Mesmo admitindo a pouca clareza do ambiente externo nas estratégias de governo, é possível verificar algumas tendências principais da nova política externa, inclusive em descompasso com os discursos que caracterizaram a candidatura de Bolsonaro. No campo da integração regional, a conclusão das negociações 
do Acordo Mercosul-União Europeia, embora garanta um novo impulso para as relaçôes cone-sulinas, abre espaço para posições contraditórias por parte do governo Bolsonaro.

Durante a campanha e o primeiro momento de governo, Bolsonaro defendeu uma perspectiva de desmonte do Mercosul, em sinalização de uma postura mais autônoma do país e menos vinculada aos desígnios regionais. Tal desejo também foi vocalizado no interior da gestấo, a partir de declaraçóes do ministro da Economia, Paulo Guedes, de que o Mercosul não seria uma prioridade para o Brasil. No entanto, conforme o Acordo Mercosul-Uniáo Europeia passou a despontar como realidade, houve um processo de amenização das posições defendidas até então. Guedes, inclusive, apontou medidas que sugeririam maior aprofundamento e institucionalização do bloco, tal qual a proposta de criação de uma moeda comum a médio e longo prazo (Mariano, 2019). De certa forma, esses movimentos dúbios expóem falhas na coordenação de posiçóes de governo e na coesão dos agentes de política externa.

Apesar desses desencontros, parece subsistir no panorama regional a manutenção de uma lógica comercialista e de liberalização herdada da gestão Temer, que concebe o Mercosul como principal plataforma de atuação regional. Para tanto, o governo Bolsonaro desvinculou-se de vez de projetos regionais oriundos dos governos petistas, a partir da formalização da saída da Unasul. Além disso, há a aposta em articulações mais flexíveis, que denotam baixo grau de comprometimento político e econômico com a estrutura organizacional, e fragmentárias, no sentido de não abranger a totalidade da América do Sul, como é o caso do Prosul.

Ademais, no governo Bolsonaro, o acirramento diplomático com a Venezuela ganha novos contornos a partir da empreitada do Itamaraty contra movimentos e regimes de inspiraçáo socialista. A luta contra as ideologias adquire maior ressonância na atuação diplomática brasileira, inclusive no âmbito de organizaçóes como o Conselho de Direitos Humanos da ONU e a Comissão de Direitos Humanos da OEA, onde diplomatas brasileiros têm sido instruídos a banir referências à "ideologia de gênero". ${ }^{32}$ A convergência de valores e crenças que passam agora a informar os agentes à frente da política externa brasileira resulta em um discurso internacional que associa as grandes mazelas contemporâneas a movimentos ideológicos de alcance global (globalismo). Esse discurso se expressa, em relação à crise venezuelana, na vinculação dos problemas sociais, econômicos e políticos à figura bolivarianista do presidente Maduro. 
Desde as primeiras atuaçóes à frente do Itamaraty, o ministro diplomata Ernesto Araújo, a despeito da carreira voltada para temáticas de integração regional e Mercosul, tem como foco aspectos mais abrangentes das relaçóes internacionais do país em detrimento de um segmento temático específico que disciplina uma linha de atuação. $\mathrm{Na}$ visão do ministro, a aproximação com os Estados Unidos visa recuperar um comportamento universalista, ou seja, que não é norteada por frentes de atuação centradas em áreas regionais, como América Latina, África e Ásia. Ao agir desse modo, o ministro acredita promover uma "reparação histórica" que promove oportunidades perdidas em décadas de política externa de caráter "antiamericanista" e "terceiro-mundista" (Funag, 2019). O primeiro ano da gestão Araújo no Itamaraty marca a diminuição do espaço conferido à América do Sul. ${ }^{33}$

Os principais influenciadores e formuladores da política externa corrente, o intelectual e filósofo Olavo de Carvalho e o deputado Eduardo Bolsonaro (PSL), que também preside a Comissão de Relaçôes Exteriores e de Defesa Nacional (CREDN) da Câmara dos Deputados, destacam um valor secundário ou mesmo inexpressivo às relaçôes do Brasil com o seu entorno regional. Ambos enfatizam o alinhamento com os Estados Unidos e a priorizaçáo do bilateralismo como modalidade de relacionamento externo. Outra questấo é que tanto Carvalho quanto Eduardo Bolsonaro formam também a ala considerada mais radical na assessoria direta da presidência, o que pode implicar um potencial conflitivo maior para os assuntos internacionais.

No que tange aos processos regionais, o governo Bolsonaro tem mantido um comportamento diplomático que se ausenta da capacidade de iniciativa. A constituição do Prosul é o indicativo mais recentes desse processo, já que emerge das articulaçôes entre os presidentes colombiano, Iván Duque, chileno, Sebastián Piñera, como forma de lançar de vez a Unasul ao ostracismo. Embora o Brasil tenha aderido ao bloco sem grandes dificuldades, a participação presidencial demonstra-se limitada. O presidente Bolsonaro, por exemplo, destacou-se como único chefe de Estado ausente na reunião para tratar da atuação conjunta dos membros do Prosul em reaçáo aos impactos da pandemia da Covid-19 (coronavírus), em março de 2020.

Um perfil de retraimento na regiáo tem sido a tônica do mandatário brasileiro. Enquanto os três últimos presidentes eleitos - Fernando Henrique Cardoso, Lula da Silva e Dilma Rousseff - privilegiaram países da América do Sul nas primeiras viagens bilaterais de Estado (Pimentel, 2019), Bolsonaro tem

33. Um dos primeiros atos do ministro Araújo foi a aprovação de uma reforma da estrutura regimental do Ministério das Relações Exteriores, por meio do Decreto № 9.683, de 9 de janeiro de 2019, o qual, entre outras coisas, outorga a área sul-americana ao Departamento de América do Sul, da Secretaria de Negociações Bilaterais e Regionais nas Américas, em que estão alocados, por seu turno, outros três departamentos: dos Estados Unidos, de México, Canadá, América Central e Caribe, e de Mercosul e Integração Regional. 
endossado um itinerário que enfatiza um realinhamento com a Casa Branca. A aproximação com o governo estadunidense tem como elo fundamental a cosmologia de visóes compartilhada entre Donald Trump e o mandatário brasileiro em torno de pautas nacionalistas, de cunho antissistema internacional e pró-armamentista, e que é demarcada na alcunha de Bolsonaro como "o Trump dos trópicos". O estreitamento de vínculos bilaterais almeja também o apoio à candidatura brasileira na OCDE.

Um último fator de estremecimento está relacionado com a principal parceria estratégica do Brasil na regiâo: a Argentina. O fato de o Planalto ter decidido se distanciar da Casa Rosada, desde que a alternância governamental na Argentina, em dezembro de 2019, favoreceu o candidato kirchnerista Alberto Fernández (Partido Justicialista), é um elemento de fragmentação regional a ser considerado nos próximos anos. Assim como pontuado por Mariano (2019), esse reposicionamento brasileiro é crucial, uma vez que a integração cone-sulina está fundamentada na relação Argentina-Brasil. É válido lembrar que, durante as eleiçóes argentinas, o governo brasileiro condicionou a manutenção do diálogo com o país à reeleição de seu aliado Maurício Macri.

\section{CONSIDERAÇÕES FINAIS}

A par das limitaçôes inerentes à análise de uma conjuntura tão dinâmica quanto a atual, 2020 inicia uma nova década para o regionalismo sul-americano, que tende a ser volátil e instável, pois, embora esse movimento seja razoavelmente recente, já demonstra e reflete três principais características em curso pelo menos nos últimos cinco anos.

Inicialmente, o enfraquecimento do regionalismo pós-hegemônico é condicionante fundamental no entendimento da dinâmica de instabilidade regional. Pensado como uma proposta com menor foco à agenda comercial e com inserçôes mais propositivas à integração política e social, tal regionalismo continuou a sustentar a preponderância dos Estados nacionais, não articulando capacidades decisórias próprias dos blocos, muito menos maiores níveis de autonomia por parte dos organismos regionais.

A Unasul, mesmo tendo sido considerada um processo inovador, de amplitude temática e de diminuição da ótica dependentista sul-americana, não conseguiu se manter ao longo do tempo. Isso ocorreu porque um dos fatores fundamentais foi o seu forte vínculo político-partidário, incluído na primeira seção do artigo como uma das variáveis principais que explicam a debilidade do regionalismo pós-hegemônico. A partir dessa constatação, indaga-se quais poderiam ser os fatores de sustentação do Prosul na década de 2020. Considerando que o foro tem menor nível de institucionalização e que se mostra mais como 
arena de diálogo e menos como bloco regional, e também reflete a guinada à direita na região, podemos concluir que seu futuro é incerto e, talvez, efêmero.

Por conseguinte, a segunda característica da conjuntura atual do regionalismo sul-americano reside no seu vínculo com as instabilidades políticas internas na região, destacando-se os casos apresentados na segunda seção. Os levantes populares na Venezuela, no Brasil, na Bolívia, no Chile e no Equador refletem não somente a histórica vulnerabilidade regional diante das mudanças sistêmicas, mas também a manutenção histórica da falta de legitimidade das instituiçôes governamentais sul-americanas em modificar suas estruturas em busca da supressão das desigualdades e assimetrias presentes dentro e entre os países no continente.

Por sua vez, os problemas inerentes ao contexto nacional sul-americano influenciam diretamente o modo pelo qual os países se posicionam dentro dos compromissos regionais assumidos. Ou seja, movimentos de instabilidade nacional retraem os espaços regionais uma vez que não são prioridade nas agendas políticas nacionais. As relaçóes cooperativas sul-americanas são frágeis e respondem a uma dinâmica intergovernamental, que, sob tensão, se desmantelam. Pode-se dizer, portanto, que em um cenário tão fragmentado, não parece haver espaço para a discussão das potencialidades de uma atuação conjunta na regiấo.

A mudança de rumos na política externa brasileira para a América do Sul conforma a terceira característica de instabilidades de regionalismo nos anos 2020. Constata-se que, diferentemente do claro apelo sul-americano que caracterizou os empreendimentos diplomáticos dos anos 2000, consubstanciado na capacidade de iniciativa do Brasil perante os processos regionais, a política externa do país passa a se caracterizar mais por sua reatividade e crescente descompromisso com seu entorno no decorrer da última década. Com as alternâncias políticas de 2016, por seu turno, os movimentos brasileiros podem ser lidos como descaracterizadores da governança regional sul-americana, mediante ampla contestaçâo da Unasul. Assim sendo, se sozinha a retração do país não dá conta de explicar toda a história, tampouco sem esse fator é possível compreender as instabilidades correntes no panorama regional.

\section{REFERÊNCIAS}

ALEM, A. C.; CAVALCANTI, C. E. O BNDES e o apoio à internacionalização das empresas brasileiras: algumas reflexóes. Revista do BNDES, v. 12, n. 24, p. 43-76, dez. 2005.

BARRENENGOA, A. C. “¿Mudar para valer?” Estado y clases dominantes en los entramados de la integración suramericana: Brasil en el Cosiplan-Unasur (2003-2011). 2019. Tese (Doutorado) - Universidade Nacional de la Plata, La Plata, 2019. 
BARROS, P. S.; GONÇALVES, J. de S. B. Fragmentação da governança regional: o Grupo de Lima e a política externa brasileira (2017-2019). Mundo e Desenvolvimento, v. 2, p. 6-39, 2019.

BIEGON, R. US power in Latin America: renewing hegemony. New York: Routledge, 2017.

BIELSCHOWSKY, R. Evolución de las ideas de la Cepal. Revista de la Cepal, número extraordinário, p. 21-46, 1998.

BRASIL. Ministério das Relaçóes Exteriores. Denúncia do Tratado Constitutivo da União de Naçōes Sul-Americanas (Unasul). Ministério das Relaçóes Exteriores, 15 abr. 2019. Disponível em: <http://www.itamaraty.gov.br/pt-BR/ notas-a-imprensa/20291-denuncia-do-tratado-constitutivo-da-uniao-de-nacoessul-americanas-unasul>. Acesso em: 15 abr. 2020.

CAETANO, G.; LÓPEZ BURIAN, C.; LUJÁN, C. Liderazgos y regionalismos en las relaciones internacionales latinoamericanas. Revista CIDOB d'Afers Internacionals, n. 121 , abr. 2019.

CARVALHO, L. Valsa brasileira: do boom ao caos econômico. Sáo Paulo: Todavia, 2018.

CERVO, A. L.; LESSA, A. C. O declínio: inserção internacional do Brasil (2011-2014). Revista Brasileira de Política Internacional, v. 57, n. 2, p. 133-151, dez. 2014. Disponível em: <https://www.scielo.br/pdf/rbpi/ v57n2/0034-7329-rbpi-57-02-00133.pdf>. Acesso em: 19 abr. 2020.

COSTA, G. D. F. da. ODR ENTREVISTA: professor dr. Camilo M. López Burian. Observatório de Regionalismo, 19 nov. 2019. Disponível em: <http:// observatorio.repri.org/artigos/odr-entrevista-professor-dr-camilo-m-lopezburian/>. Acesso em: 17 abr. 2020.

CRIES - COORDINADORA REGIONAL DE INVESTIGACIONES ECONÓMICAS Y SOCIALES. Crise no Brasil e seu impacto regional. Medium, 2 maio 2016. Disponível em: <https://medium.com/@CRIESLAC/crise-nobrasil-e-seu-impacto-regional-4f95f9a 1e2ef>. Acesso em: 19 out. 2018.

FUCCILLE, A. et al. O governo Dilma Rousseff e a América do Sul: a atuação brasileira na Unasul (2011-2014). Colombia Internacional, v. 92, p. 43-72, 2017. Disponível em: <http://www.scielo.org.co/pdf/rci/n92/0121-5612rci-92-00043.pdf>. Acesso em: 10 jan. 2018.

FUNAG - FUNDAÇÃO ALEXANDRE DE GUSMÃO. Discurso do embaixador Ernesto Araújo na cerimônia de posse no Ministério das Relaçóes Exteriores. Brasília: Funag, 2 jan. 2019. Disponível em: <http://funag.gov.br/ index.php/pt-br/component/content/article?id=2913>. Acesso em: 23 mar. 2020. 
HONÓRIO, K. dos S. O significado da Iniciativa para a Integraçáo da Infraestrutura Regional Sul-americana (IIRSA) no regionalismo sul-americano (2000-2012): um estudo sobre a iniciativa e a participação do Brasil. 2013. 135 f. Dissertação (Mestrado) - Programa de Pós-Graduação em Relações Internacionais San Tiago Dantas, Universidade Estadual Paulista Júlio de Mesquita Filho, Universidade Estadual de Campinas, Pontifícia Universidade Católica de São Paulo, São Paulo, 2013.

A política das obras e as obras da política: um estudo sobre as relaçōes bilaterais Brasil-Bolívia e Brasil-Equador na dimensão da infraestrutura nos governos Lula da Silva (2003-2010). 2019. 228 f. Tese (Doutorado) - Programa de Pós-Graduação em Relações Internacionais San Tiago Dantas, Universidade Estadual Paulista Júlio de Mesquita Filho, Universidade Estadual de Campinas, Pontifícia Universidade Católica de São Paulo, São Paulo, 2019.

HRW - HUMAN RIGHTS WATCH. O êxodo venezuelano. Human Rights Watch, 3 set. 2018. Disponível em: <https://www.hrw.org/pt/ report/2018/09/03/322156>. Acesso em: 14 abr. 2020.

JAGUARIBE, H. Autonomia e hegemonia no sistema imperial americano (1987). In: . Brasil, mundo e homem na atualidade: estudos diversos. Brasília: Funag, 2008. p. 163-209.

JUNQUEIRA, C. G. B.; MILANI, L. P. "Regionalismo governamental" sul-americano: deficiências institucionais e dependência internacional. Mundo e Desenvolvimento, v. 2, n. 3, p. 65-88, 2019.

LEVI, M. El despertar ecuatoriano. Foreign Affairs Latinoamérica, v. 20, n. 2, p. 53-58, 2020.

LOPES, D. B.; BURIAN, C. L. La política exterior brasileña del siglo XXI: un cambio epocal. In: BRUN, D. A.; FLORENTÍN, C. G. (Org.). Panorama de las relaciones internacionales en el Paraguay actual. 1. ed. Asunción: Editora UNA, 2018. p. 99-130.

MALAMUD, A. Overlapping regionalism, no integration: conceptual issues and the Latin American experiences. Fiesole: EUI, 2013. (Working Paper, n. 2013/20).

- ¿Por qué estalla Latinoamérica? Foreign Affairs Latinoamérica, v. 20, n. 2, p. 2-8, 2020.

MALAMUD, A.; GARDINI, G. L. Has regionalism peaked? The Latin American quagmire and its lessons. The International Spectator, v. 47, n. 1, p. 116-133, 2012. Disponível em: <https://www.tandfonline.com/doi/abs/10.1080/039327 29.2012.655013>. Acesso em: 29 set. 2017. 
MALAMUD, A.; SCHMITTER, P. C. The experience of European integration and the potential for integration in South America. Barcelona: IBEI, 2007. (Working Paper, n. 2007/6).

MARIANO, K. L. P. Algumas reflexōes sobre o acordo Mercosul-União Europeia. Observatório de Regionalismo, 30 jul. 2019. Disponível em: <http:// observatorio.repri.org/artigos/algumas-reflexoes-sobre-o-acordo-mercosuluniao-europeia/>. Acesso em: 17 abr. 2020.

MARIANO, K. L. P.; RIBEIRO, C. C. N. Regionalismo na América Latino no século XXI. In: SALATINI, R. (Org.). Cultura e direitos humanos nas relaçóes internacionais: reflexôes sobre cultura. 1. ed. São Paulo: Cultura Acadêmica, 2016. v. 1, p. 23-40.

MIJARES, V. M.; RAMÍREZ, S. El factor Venezuela en la crisis del regionalismo post-hegemónico. Working Paper, 2020.

MIJARES, V. M.; ROJAS SILVA, N. Venezuelan migration crisis puts the region's democratic governability at risk. Hamburg: Giga, 2018. (Giga Focus Lateinamerika, n. 6). Disponível em: <https://nbn-resolving.org/urn:nbn:de:0168-ssoar-59911-3>.

NEVES, B. C. Política externa brasileira e a integraçáo da infraestrutura na América do Sul: uma análise a partir dos mecanismos IIRSA/Cosiplan. 2019. 249 f. Dissertação (Mestrado) - Programa de Pós-Graduação em Relações Internacionais San Tiago Dantas, Universidade Estadual Paulista Júlio de Mesquita Filho, Universidade Estadual de Campinas, Pontifícia Universidade Católica de São Paulo, São Paulo, 2019.

NEVES, B. C.; HONÓRIO, K. Latin American regionalism under the new right. E-International Relations, 27 Sept. 2019. Disponível em: <https://www.e-ir. info/2019/09/27/latin-american-regionalism-under-the-new-right/>.

NOLTE, D. Lo bueno, lo malo, lo feo y lo necesario: pasado, presente y futuro del regionalismo latinoamericano. Revista Uruguaya de Ciencia Política, v. 28, n. 1, p. 131-156, 2019.

OEA - ORGANIZACIÓN DE LOS ESTADOS AMERICANOS. Análisis de integridad electoral: elecciones generales en el Estado Plurinacional de Bolivia. La Paz: OEA, 2019. Disponível em: <http://www.oas.org/es/sap/deco/ Informe-Bolivia-2019/0.1\%20Informe\%20Final\%20-\%20Analisis $\% 20 \mathrm{de} \% 20$ Integridad\%20Electoral\%20Bolivia\%202019\%20(OSG).pdf>. Acesso em: 16 abr. 2020.

PAIKIN, D.; PERROTTA, D. La Argentina y la Alianza del Pacífico: riesgos y oportunidades de una nueva geopolítica. Aportes para la Integración Latinoamericana, v. 22, n. 34, p. 67-101, jul. 2016. 
PALESTINI, S. De Unasur a Prosur, ¿̨rebautizo o reforma? Opinión Internacional, 13 mar. 2019. Disponível em: <https://opinion.cooperativa.cl/opinion/internacional/ de-unasur-a-prosur-rebautizo-o-reforma/2019-03-13/064919.html>. Acesso em: 15 abr. 2020.

PIMENTEL, M. As viagens ao exterior de presidentes em 100 dias de governo. Nexo, 3 abr. 2019. Disponível em: <https://www.nexojornal.com.br/ expresso/2019/04/03/As-viagens-ao-exterior-de-presidentes-em-100-dias-degoverno>. Acesso em: 20 abr. 2020.

PINI, A. M. A crescente presença chinesa na América Latina: desafios ao Brasil. Boletim de Economia e Política Internacional, n. 21, p. 21-31, set./dez. 2015. PMDB - PARTIDO DO MOVIMENTO DEMOCRÁTICO BRASILEIRO. Uma ponte para o futuro. Brasília: Fundação Ulysses Guimarães, 2015. Disponível em: <https://www.fundacaoulysses.org.br/wp-content/uploads/2016/11/UMAPONTE-PARA-O-FUTURO.pdf>. Acesso em: 20 abr. 2020.

RIBEIRO, C. C. N. Overlapping organizations, political crises, and coexistence: complementarity and fragmentation in South American and African Regionalisms. 2020. Tese (Doutorado) - Universidade Estadual de Campinas, Campinas, 2020.

RIGGIROZZI, P.; TUSSIE, D. (Ed.). The rise of post-hegemonic regionalism: the case of Latin America. Dordrecht: Springer, 2012.

SANAHUJA, J. A. Del "regionalismo abierto" al "regionalismo post-liberal": crisis y cambio en la integración regional en América Latina. In: ANUARIO DE LA INTEGRACIÓN REGIONAL DE AMÉRICA LATINA Y EL GRAN CARIBE 2008-2009, 7., 2009, Buenos Aires, Argentina. Anais... Buenos Aires: Cries, 2009. p. 11-54.

Crisis de la globalización, el regionalismo y el orden liberal: el ascenso mundial del nacionalismo y la extrema derecha. Revista Uruguaia de Ciência Política, v. 28, n. 1, p. 59-94, jun. 2019. Disponível em: <http://www.scielo. edu.uy/scielo.php?script=sci_arttext\&pid=S1688-499X2019000100059\&lng=e s\&nrm=iso >. Acesso em: 20 abr. 2020.

SANTOS, S. C. El proceso de integración del Mercosur a través de las teorías de la integración regional. Montevideo: Cefir, 2011. (Documento de Trabajo, n. 12).

SARAIVA, M. G. Integração regional na América do Sul: processos em aberto. In:ENCONTRONACIONALDAASSOCIAÇÃOBRASILEIRASDASRELAÇŌES INTERNACIONAIS - GOVERNANÇA GLOBAL E OUTROS ATORES, 3., 2011, São Paulo. Anais... São Paulo: ABRI, 2011. Disponível em: <http://www. proceedings.scielo.br/scielo.php?pid=MSC0000000122011000300028\&script=sci_ arttext>. Acesso em: 10 jun. 2018. 
Encontros e desencontros: o lugar da Argentina na política externa brasileira. Belo Horizonte: Fino Traço, 2012.

. Estancamento e crise da liderança do Brasil no entorno regional. In: ANUARIO DE LA INTEGRACIÓN REGIONAL DE AMÉRICA LATINA Y EL GRAN CARIBE, 10., 2016, Buenos Aires, Argentina. Anais... Buenos Aires: Cries, 2016. p. 295-310.

SARAIVA, M. G.; VELASCO JÚNIOR, P. A. A política externa brasileira e o "fim de ciclo" na América do Sul: para onde vamos? In: SANAHUJA, J. A. (Ed.). Pensamiento propio. Buenos Aires: Cries, 2016. v. 21. p. 295-324. Disponível em: <http://www. cries.org/wp-content/uploads/2017/02/PP44-web.pdf>. Acesso em: 20 jun. 2018.

SERBIN, A. Regionalismo y soberanía nacional en América Latina: los nuevos desafíos. Buenos Aires: Cries; Nueva Sociedad, 2010. (Documento Cries, n. 15).

SOUZA, L. E. S. de. O Brasil e o regionalismo sul-americano: o papel da Unasul na política externa do governo Rousseff (2011-2016). 2018. 156 f. Dissertação (Mestrado) - Universidade de Brasília, Brasília, 2018.

SOUZA, L. E. S. de; TELAROLLI, M. L. Jair Bolsonaro. In: GONÇALVES, J. de S. B.; SOUZA, L. E. S. de. (Coord.). Política externa e regionalismo: os programas dos presidenciáveis nas eleiçóes de 2018. São Paulo: ODR, 2018. Disponível em: <http://observatorio.repri.org/wp-content/uploads/2018/09/ ODR-Eleicoes_PEB_2018.pdf>.

SPYKMAN, N. J. America's strategy in world politics: the United States and the balance of power. New York: Harcourt, Brace and Company, 1942.

TOKATLIAN, J. G. América Latina camina hacia la debilidad y la desintegración. Nueva Sociedad, feb. 2019. Disponível em: <https://nuso.org/articulo/americalatina-camina-hacia-la-debilidad-y-la-desintegracion/>. Acesso em: 20 abr. 2020.

VALDIVIESO, C. Equador em crise: as dimensōes da violência nas manifestaçóes de outubro. Manifesto, 5 dez. 2019. Disponível em: <https://canalmanifesto. com/2019/12/05/equador-em-crise/>. Acesso em: 7 abr. 2020.

VÁSQUEZ, M.; RUIZ, J. B. O Mercosul na época de Lula e Kirchner: um balanço, seis anos depois. Nueva Sociedad, p. 33-48, dez. 2009.

VEIGA, P. da. M.; RÍOS, S. P. O regionalismo pós-liberal na América do Sul: origens, iniciativas e dilemas. Santiago: Cepal, 2007. (Série Comércio Internacional, n. 82).

VITELLI, M.; MILANI, L. P. Regionalismo sudamericano en tiempos de redefiniciones: el Consejo de Defensa de la Unasur y la crisis del regionalismo posliberal y poshegemónico. Revista Uruguaya de Ciencia Política, v. 28, n. 2, p. 35-59, 2019. 